\title{
The ancestors of Norman Bethune (1890- 1939) traced back to the Bethunes of Skye, leading members of the MacBeth/Beaton medical dynasty
}

\author{
${ }^{1}$ A Munro, ${ }^{2}$ IMC Macintyre \\ ${ }^{1}$ Retired Surgeon and Personal Chair, University of Aberdeen at the Centre for Health Science, Inverness, UK; ${ }^{2}$ Retired Surgeon and History \\ Editor of the Journal of the Royal College of Physicians of Edinburgh
}

\begin{abstract}
Norman Bethune became famous through his work in the Spanish Civil War, his advocacy of socialised medicine in North America and his association with Mao Zedong's revolutionary movement in China. It has been suggested that he may have been descended from the Bethune or Beaton medical dynasty, who for generations served as physicians to kings of Scotland, the Lords of the Isles and to some of the larger Scottish clans. This paper traces his lineage back to the Isle of Skye. In the absence of old parish records as aids to tracing genealogy, other available evidence has confirmed that Bethune was indeed in the direct line of descent from the Bethunes or Beatons of Husabost, in Skye, one of the largest branches of this medical kindred, who were physicians to the MacLeods of Dunvegan.
\end{abstract}

\author{
Correspondence to I Macintyre \\ 20 Lygon Road \\ Edinburgh EHI6 5QB \\ UK \\ tel. $+44(0) 1314660095$ \\ e-mail \\ iainmacintyre@blueyonder.co.uk
}

KEYWORDS Ancestors, Beaton/Bethune medical kindred genealogy, Norman Bethune

DECLARATIONS OF INTERESTS lain Macintyre is the History Editor of The Journal of the Royal College of Physicians of Edinburgh. This article was submitted to, and handled exclusively by, the JRCPE's Editor and has been peer-reviewed in line with usual JRCPE procedures.

The Canadian surgeon Henry Norman Bethune (18901939) (Figure I) was once described as 'the world's best known surgeon.' His fame resulted initially from his promotion of free medical care in Canada, from his work on mobile blood transfusion units during the Spanish Civil War, but most especially from Mao Zedong's appreciation of the work he did to develop surgical training and mobile surgical units for the Eighth Route army after the Japanese invasion of China in 1937. Bethune died while working as a surgeon in Mao's army and the story of his heroism and dedication (what Mao called 'Comrade Bethune's spirit, his utter devotion to others without any thought of self') $)^{2}$ became required reading in Chinese schools. Although he was idolised in China, his standing in the West was tainted by his difficult personality, his membership of the communist party in Canada and his advocacy of socialised medicine in North America. It was many years before his reputation in theWest was rehabilitated as a result of changing attitudes and the publication of a number of books and films about his remarkable life.

Bethune qualified MD in Toronto in 1916 and after service as a surgeon sub-lieutenant in the Royal Navy in the First World War he remained in Britain for surgical

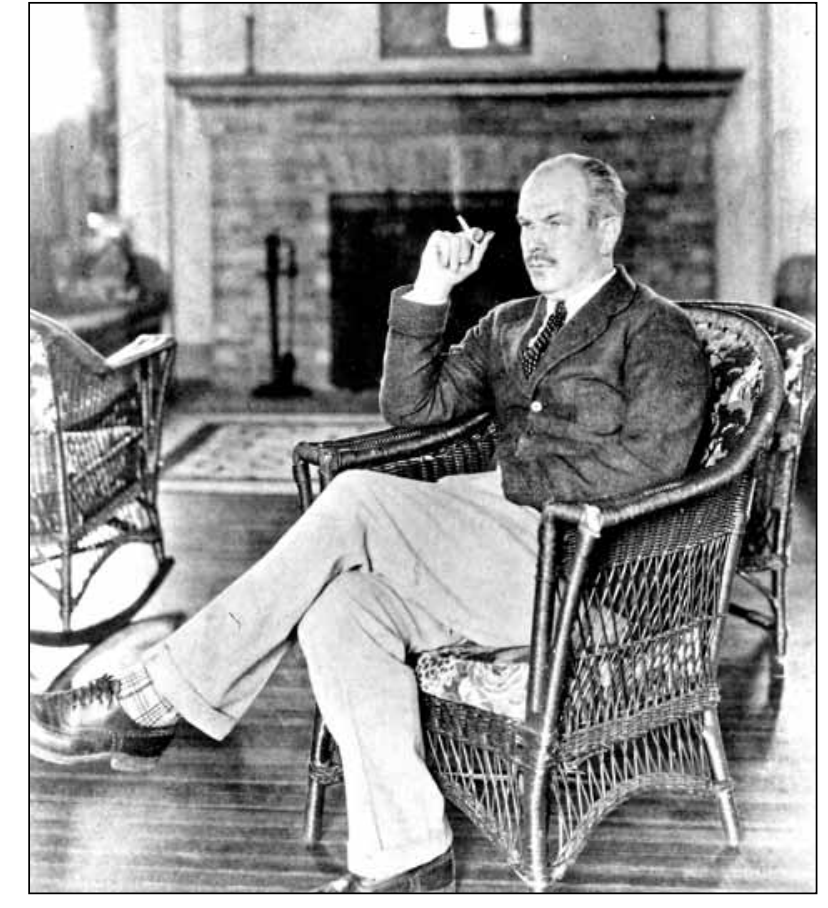

FIGURE I Norman Bethune, characteristically defiant, smoking while a patient in the Trudeau Sanitorium in New York State. Image courtesy of Roderick Stewart. 
training. This included time in Edinburgh where he met and married a local girl, Frances Penney, whom he would later divorce, remarry and divorce again. In 1922 he qualified, as his grandfather had done before him, as a Fellow of the Royal College of Surgeons of Edinburgh.

Bethune once claimed that 'I come of a race of men, violent, unstable, of passionate convictions and wrongheadedness, intolerant, yet with it all a vision of truth and a drive to carry them on to it even though it leads, as it has done in my family, to their own destruction', ${ }^{2}$ a quotation which has been interpreted as referring to his Scottish ancestry. Biographers have suggested that he may have been descended from the Beatons, a dynastic medical family, who from the 14th to the 18th century, served as physicians to clan chiefs and other landed families in the Highlands and Islands of Scotland and were physicians to the kings of Scots. Yet the detail of the link between Henry Norman Bethune and the Beatons has not to our knowledge been published and the present study was undertaken to explore this connection.

\section{ANCESTORS OF HENRY NORMAN BETHUNE IN NORTH AMERICA}

\section{Rev Malcolm Nicholson Bethune (I 857-1932)}

Henry Norman Bethune's ancestry in North America has been extensively researched and is well established. His father, Rev Malcolm Nicholson Bethune (1857-1932), was born in Toronto, the son of a doctor. ${ }^{2,3}$ Influenced by the evangelical movement of Moody and Sankey he became a clergyman, serving as a Presbyterian minister in Ontario where his sermons were renowned for an emphasis on the dangers of alcohol abuse. He had seen at first hand the results of alcohol excess in his father.

\section{Norman Bethune (I822-92)}

Malcolm's father, Norman Bethune (I822-92) (Figure 2), had been the first doctor in his family for a number of generations. ${ }^{3,4} \mathrm{He}$ was born in Moose Factory, Ontario, where his father had been chief factor for the Hudson's Bay Company (HBC). After completing an arts degree at King's College in Toronto he studied at the College's Medical School in 1845-6 and subsequently at Edinburgh and King's College and Guy's Hospital in London, qualifying MRCS in 1848. While in Edinburgh he met and married Janet Nicolson who came from the small community of Husabost in northern Skye, from where his own ancestors could trace their roots.

After returning to Toronto he was involved in establishing the city's third Medical School, the Upper Canada School of Medicine, which became the Medical Faculty of the Anglican Trinity College. He became Dean of the Faculty of Medicine in 1855 and later taught anatomy at the

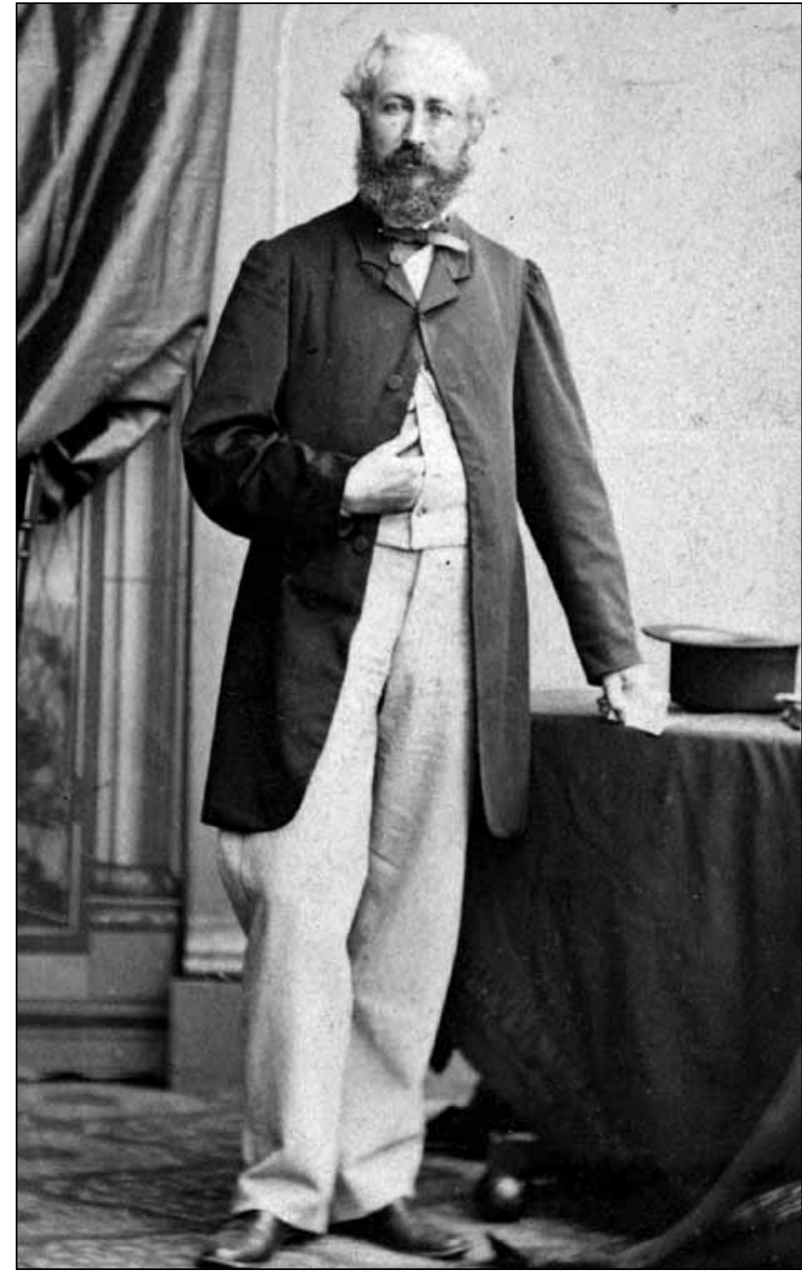

FIGURE 2 Norman Bethune senior (1822-92). Anatomist, surgeon and Norman Bethune's grandfather, who despite his flaws was respected by his grandson. Image courtesy Archives of Ontario Legislative Library print collection.

Toronto School of Medicine before travelling back to Edinburgh where he became a Fellow of the Royal College of Surgeons in 1860. He practised medicine in Edinburgh until 1869 and, on returning to Canada, held a chair of medicine and later surgery in Toronto until 1881. A combination of inability to manage his finances and alcohol abuse led to the loss of his university appointment and the breakup of his family. Unstable, but without doubt a man of vision, perhaps it was his grandfather that Henry Norman Bethune had in mind when he wrote about his unstable ancestors. Yet for all his failings, the younger Bethune held his grandfather in high esteem for his undoubted achievements, so it is important to look further back in his family tree for those qualities he believed he had inherited.

Angus Bethune (I783-I858)

The father of Norman Bethune (senior), Angus Bethune (1783-1858), had as a young man joined the North West Company, whose headquarters were in Montreal near to where he grew up. Its leaders were, like his parents and 
forebears, Highland Scots. He rose to become a partner in the company and a successful explorer, fur trader and businessman who travelled throughout Canada and even to China. ${ }^{5} \mathrm{He}$ went on to become a chief factor of the $\mathrm{HBC}$ and a director of the Bank of Upper Canada. ${ }^{6}$

Yet he too seemed to have some of the unfavourable characteristics that Henry Norman Bethune attributed to his ancestors. Sir George Simpson (c. 1787-1860), the Dingwall-born governor of the $\mathrm{HBC}$, gave this unflattering description: 'a very poor creature, vain, self sufficient and trifling, who makes his own comfort his principal study; possessing little Nerve and no decision in anything: of a snarling vindictive disposition, and neither liked nor respected by his associates, Servants [HBC workers] or Indians."

\section{Rev Dr John Bethune (c.I75I-18I5) in Canada}

Angus Bethune's father, Rev Dr John Bethune (c.175I1815), provides the link between Bethune's forebears in North America and those in Scotland. He arrived in North Carolina from Skye in 1773 as a licentiate minister of the Church of Scotland. Two years later he was recruited as chaplain to the Ist Battalion of the Royal Highland Emigrants, a regiment of émigré Highland Scots loyal to the Crown during the American War of Independence. The first battalion had been raised by Colonel Allan Maclean to defend present-day Ontario, Quebec and Atlantic Canada from attack by American Revolutionaries. After the defeat of the Royal Highland Emigrants at the battle of Moore's Creek Bridge in February 1776, Bethune was imprisoned by the victorious rebels, along with hundreds of other émigré Scottish Highlanders. For a time he was held in a Philadelphia prison before being released by the Continental Congress and making his way to Halifax, Nova Scotia, where the 2nd Battalion of the Royal Highland Emigrants was stationed. ${ }^{8}$

There he was appointed chaplain to the regiment by Captain MacDonald who described him as 'a young man of very good character, tho' a Presbyterian'. ${ }^{8}$ Subsequently he moved with other Empire Loyalists to Montreal, where, in the absence of a Presbyterian church, he attended the services conducted by the Anglican rector of Montreal, David Delisle, who conducted his marriage to Véronique Waddens in September 1782.

By 1786, Rev John Bethune had enough parishioners to form the first Presbyterian congregation in Canada. He continued to minister to his small congregation until May 1787 when on the invitation of a group of Highland settlers he moved to Glengarry County at the easternmost area of the province, soon to become Upper Canada.
Bethune devoted the remainder of his life to his family of six sons and three daughters and to his ministry among the Highland settlers in Glengarry County, Upper Canada. His ability to preach in Gaelic placed him in good standing with his new flock, and the welcome he received was repaid with years of dedicated service. He died on 23 September 1815 in Williamstown, Glengarry, Ontario. The Dictionary of Canadian Biography describes him as 'the most honored and respected of Canada's pioneer Church of Scotland ministers.. ${ }^{10}$ We know something of his life in Scotland before he emigrated.

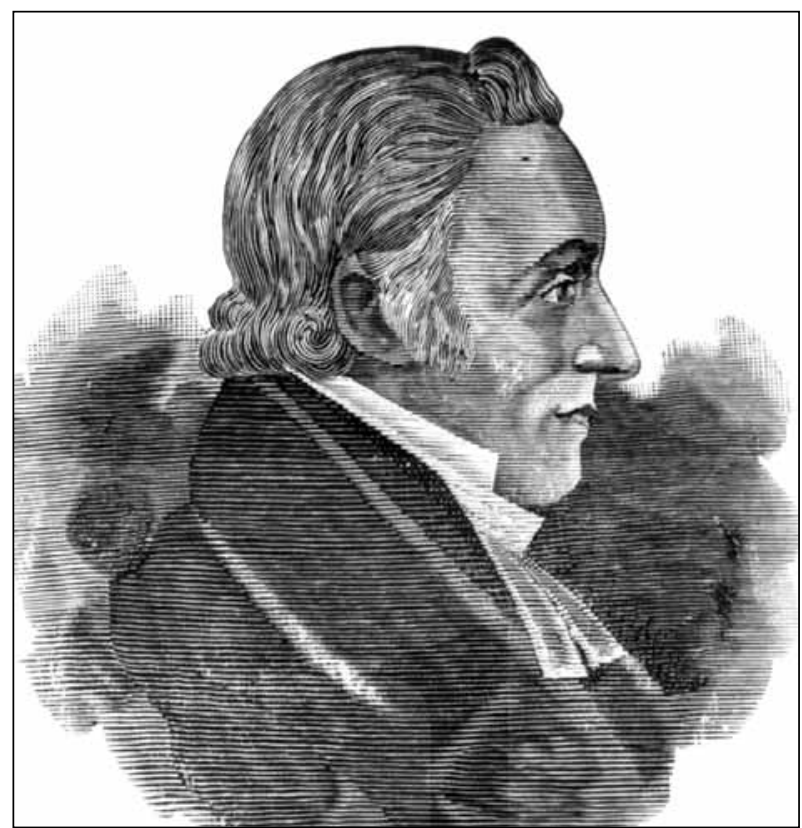

FIGURE 3 Rev John Bethune, cl75I-|8|5, who emigrated from Skye to North America. ${ }^{4}$

\section{ANCESTORS OF HENRY NORMAN BETHUNE IN SKYE, SCOTLAND}

Tracing ancestry in Skye before 1800 is made particularly difficult because of the lack of old parish records, the usual source of information about births, deaths and marriages in Scotland in the years before statutory records began in 1855. Two principal sources, however, are available:Whyte and Bannerman. Rev Thomas Whyte (c. 1718-89) was minister of Liberton Kirk in Edinburgh and had married into the Bethune family. In 1778 he published An Historical and Genealogical Account of the Bethunes of the Island of Sky [sic]." Whyte's account gives detailed genealogy but rarely gives dates. The Scottish historian John Bannerman (1932-2008) who analysed the genealogy in Whyte's account concluded that it was 'on the whole accurate' as the period concerned was 'well within the capabilities of the contemporary kinbased genealogist'. '2 Bannerman himself published what has become the standard work of reference on the topic, The Beatons: a Medical Kindred in the Classical Gaelic 
Tradition. ${ }^{12}$ By studying relevant Gaelic documents he was able to assign some dates to events associated with many of the family members. (An explanation of the relationship between the names Bethune and Beaton is given below.)

\section{Rev Dr John Bethune (c.I75I-I8I5) in Skye}

John Bethune (c.|75I-I8I5) whose life in America and Canada has been described in the previous section was, as shown below, descended from the Bethunes/Beatons of Husabost in Skye, one of the largest and most influential branches of the medical kindred. He was born in Breabost in the parish of Duirinish in northern Skye and studied at the University of Aberdeen where he obtained a bursary in his third year of study. The following year the Synod of Glenelg granted his family $£ 5$ to help meet expenses for his education. ${ }^{13}$ After graduating with the degree of BA in 1769 and of MA in 1772, Bethune returned to Skye and was made a licentiate Church of Scotland minister by the Presbytery of Skye. ${ }^{14}$ This was a time of mass emigration from the island of Skye, particularly to North America. A letter from Allan MacDonald suggests that some 1,700 individuals emigrated from the island between $177 \mid-3 . .^{15}$ His wife Flora MacDonald, the Jacobite heroine, wrote of the privation on 'this poor miserable island' where 'the best of its inhabitants are making ready to follow their friends to America... because in Skye ....we can promise ourselves but poverty and oppression'.16 (Surprisingly both MacDonalds were ardent loyalists, prominent in recruiting for the Royal Highland Emigrants. After Allan MacDonald's capture at Moore's Creek Bridge, both moved like Bethune to stay in Nova Scotia before returning to Skye.)

The emigrations to North Carolina, largely led by tacksmen (land tenants) like the Bethunes, were bound up intimately with the disintegration and collapse of the traditional clan-based society of which the Bethune/Beaton kindred had been a key component for many generations. . $^{17,18}$

In 1773 John Bethune emigrated to North Carolina, a haven for Highland emigrants, who had established a number of colonial settlements there. He settled in McLendon's Creek in what is now Moore County, to join his mother Christian and his maternal grandparents Donald and Katherine Campbell, who had all emigrated earlier. ${ }^{8}$ It is important to note that his name is given as Bethune in Fasti Ecclesiae Scotanae, ${ }^{14}$ in Whyte's account ${ }^{11}$ and in Canadian biographies., ${ }^{3,10,19}$ John Bethune is found in Whyte's family history, written only five years after his departure for America. Whyte describes him as having gone to America and become 'a chaplain in Colonel McLean's Royal Highland Emigrants', thus clearly establishing that he was the same John Bethune described above.

\section{Angus Bethune (born c. I722)}

John Bethune's parents were Angus Bethune and his wife Christian Campbell of Scalpay. Angus was born about 1722 in Breabost in Skye and he followed his son to North America in 1776, living first in Cumberland County, North Carolina, and during 1789 in Charlottenburgh, Glengarry, Ontario., ${ }^{9}$ The date of his death is not known, but his wife Christian died in Moore County in 1784 or $85 .^{8}$

\section{John Bethune of Brebost and John Bethune of Skeabost}

According to Whyte, Angus was the son of John Bethune (born in the later years of the 17th century) who 'held the title of Brebost', a small community which lies near the village of Edinbane in northern Skye (Figure 4). This suggests that he held the tack (or rented the land) of Brebost (subsequently spelt Breabost) from the landowner. He married Margaret MacLeod of Gesto, in central Skye, but little more is known of him. His father John Bethune of Skeabost was born in the mid-17th century and he too married a MacLeod of Gesto, Marguerite. Skeabost is a community lying to the south of Breabost at the mouth of the river Snizort. Neither of these John Bethunes appears to have been a doctor."

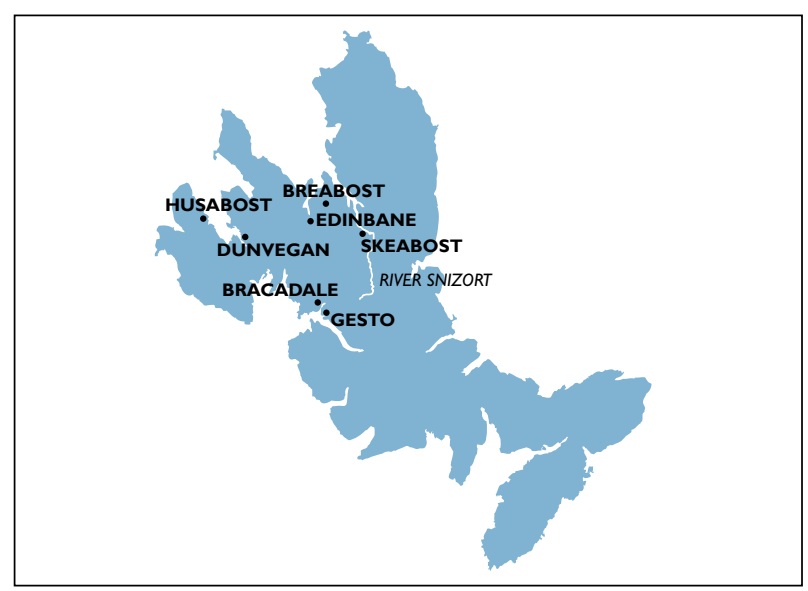

FIGURE 4 Outline map of Skye showing locations where some of Norman Bethune's ancestors were known to have lived.

\section{Farquhar Bethune}

The father of John of Skeabost was called Farquhar (or in Gaelic, Fearchar), a forename widely used in this and in other branches of the Bethune family. Farquhar was probably born in the early years of the 17th century, son of the 'second Dr Angus', a well-known member of the medical dynasty. Farquhar was not a doctor and one of the reasons given by him for not pursuing a medical career was that his father had required to study for 27 years before he 'appeared as' a physician." Whyte records that he was 'a wise and judicious man'." 


\section{Angus Bethune, the 'second Dr Angus'}

His father, the 'second Dr Angus', is known to have trained at Dunollie near Oban with Duncan Ó Conchobhair (O'Conacher or O'Connor), a member of another dynastic medical family who were physicians to the MacDougalls of Dunollie. Dr Angus is known to have written a compendium of medical treatises between $16 \mathrm{II}$ and 1614 , a substantial document running to 476 pages, now in the National Library of Scotland as Gaelic manuscript MSS LX (Adv.MS.72.2.10). ${ }^{21}$ These treatises may well have formed part of his training, as a note by him on II January 1613 includes the phrase (in Gaelic) 'it is Duncan [Ó Conchobhair] who gave me this book to write'. The manuscript includes translations into Gaelic of classical medical works including The Book of Prognostics from the Hippocratic Corpus, which he finished in August $161 \mathrm{I}$ and Galen's Anatomia, which he completed the following January. The treatises cover a wide range of topics, including urine examination, fevers, diseases of the eye, bullet wounds and there are a number on diet and drugs. ${ }^{22}$

\section{The Lily of Medicine}

By 1624 Dr Angus had become physician to Sir Ruari Mor MacLeod of Dunvegan (who died in 1626). ${ }^{22}$ According to Whyte, the second Dr Angus 'wrote a system of physic, entitled the Lily of Medicine, which he finished at the foot of Montpelier, after he had studied physic twenty-eight years'." Whyte states that this was written in Irish, probably meaning in this context a form of Classical Gaelic. No such volume survives and it is more likely that this was in fact a Scots Gaelic translation of an earlier Lily of Medicine published in 1307 by the influential physician Bernard de Gordon (1270-ca.1330), who was professor of medicine at Montpelier. Some writers have suggested he was a Scot, ${ }^{23}$ but it is more likely that he was French. ${ }^{24}$ The Lily of Medicine was an extensive compendium of medical practice in which de Gordon questioned Galenic dogma. In a major change to conventional thinking he not only described clinical features of disease, but crucially related these to anatomical changes in organs, some 400 years before Morgagni, who is generally credited as the originator of this organ-based approach. In addition, the Lily gave a practical guide to treatment. Translating its 163 chapters would have been a monumental task, but provided Gaelic practitioners with arguably the most valuable text of its day.

A copy of the Husabost Bethune family's Gaelic translation of the Lily of Medicine is now in the National Library of Scotland (Lilium Medicinae MS 2076), having been donated to the Society of Antiquaries of Scotland in 1784 by Rev Donald MacQueen, minister of Kilmuir in Skye, who had inherited it from a Bethune predecessor. ${ }^{25,28,39}$ MacQueen wrote an accompanying note, stating that the book had been owned by Farquhar
Beaton of Husabost 'five generations previously'. The second Dr Angus's father, 'Farquhar senior' seems the most likely candidate as that early owner of the volume. The note goes on to attest to the value which Farquhar placed on the Lilium Medicinae, saying that 'when he trusted himself to a boat to attend to any patient in Dunvegan, he sent his servant by land for the greater security, with the Lilium Medicinae. ${ }^{25}$ Whyte seems to have been wrong in his suggestion about the authorship of the book and similarly there is no evidence to support his statement that the second DrAngus studied at Montpelier.

\section{Farquhar Bethune senior}

Angus's father, Farquhar Bethune ('Farquhar senior'), was also a physician, and although his birthdate is not known it is likely that he was 'Fergardus Leich' (Fergus the Doctor) who witnessed an instrument of sasine in 154I described in the Dunvegan muniments. ${ }^{22}$ His designation as 'Fergardus Leich' in this context indicates that he was physician to the MacLeods of Dunvegan, one of the largest and most powerful of the Scottish clans. Whyte describes Farquhar senior as 'a grave judicious man, and of good skill in physic'. He was said to have 'the gravity of the Divine, as well as skill of the Physician'."

\section{Angus Bethune, 'the first Dr Angus'}

The father of Farquhar senior was Angus Bethune, 'the first Dr Angus'. He was also physician to the MacLeods of Dunvegan, having signed himself 'Angusius Leich' in a legal document in November 1540.22 Whyte records that he was 'a prudent man and of good esteem in the country, and tho' the M'Donalds and M'leods, the most powerful clans in the country, were often at variance, yet he was loved and much caressed by both sides."

Tracing the genealogy back further than the first $\mathrm{Dr}$ Angus (Figure 5) becomes controversial. Whyte claims a line of forebears extending to the Bethunes of Balfour in Fife, but more recent studies do not support this. The physician and Gaelic scholar HC Gillies, ${ }^{26,27}$ Donald MacKinnon, Professor of Celtic Language and Literature at Edinburgh University, ${ }^{25,28,29}$ and the historian John Bannerman ${ }^{12}$ who all studied the relevant original Gaelic manuscripts, concluded that this was not so. These authors suggest that the Bethune medical dynasty described above was descended from the MacBeths of Islay, whose roots can be traced back to the 14th century and who came originally from Ireland. Ireland had a long established tradition of physicians, educated in the great European medical schools such as Louvain and Padua, and serving noble families. The MacBeths are likely to have emerged from this tradition. 


\begin{tabular}{|c|}
\hline $\begin{array}{c}\text { Angus [fl. I540] } \\
\text { ('First Dr Angus'. Physician to the MacLeods } \\
\text { of Dunvegan) }\end{array}$ \\
\hline $\mathbf{V}$ \\
\hline $\begin{array}{c}\text { Farquhar [fl.I54I] } \\
\text { ('Farquhar senior'. Physician to the } \\
\text { MacLeods of Dunvegan) }\end{array}$ \\
\hline $\mathbf{V}$ \\
\hline $\begin{array}{c}\text { Angus [fl. } 16 \mid 0-24] \\
\text { ('Second Dr Angus'. Physician to the } \\
\text { MacLeods of Dunvegan) }\end{array}$ \\
\hline $\mathbf{V}$ \\
\hline $\begin{array}{l}\text { Farquhar [probably born early } \\
\text { I7th century] } \\
\text { ('a wise and judicious man') }\end{array}$ \\
\hline $\boldsymbol{V}$ \\
\hline $\begin{array}{l}\text { John of Skeabost (born around mid- } \\
\text { 17th century) } \\
=\text { Marguerite MacLeod of Gesto }\end{array}$ \\
\hline $\boldsymbol{V}$ \\
\hline $\begin{array}{l}\text { John of 'Brebost' (born later years of } \\
\text { 17th century) } \\
=\text { Margaret MacLeod of Gesto }\end{array}$ \\
\hline $\mathbf{y}$ \\
\hline $\begin{array}{l}\text { Angus (born c. } 1722 \text { in Breabost) } \\
=\text { Christian Campbell of Scalpay }\end{array}$ \\
\hline$\gamma$ \\
\hline $\begin{array}{c}\text { Rev John (born c. } 1751 \text { in Breabost, d 1815) } \\
\text { Emigrated to North America }\end{array}$ \\
\hline $\boldsymbol{V}$ \\
\hline $\begin{array}{l}\text { Angus (1783-1858) } \\
\text { Factor, Hudson's Bay Company }\end{array}$ \\
\hline $\mathbf{V}$ \\
\hline $\begin{array}{l}\text { Norman (1822-92) } \\
\text { Physician and surgeon }\end{array}$ \\
\hline $\mathrm{V}$ \\
\hline $\begin{array}{l}\text { Rev Malcolm (I857-1932) } \\
\text { Presbyterian clergyman }\end{array}$ \\
\hline $\mathbf{V}$ \\
\hline $\begin{array}{l}\text { Henry Norman (1890-1939) } \\
\text { Surgeon and political activist }\end{array}$ \\
\hline
\end{tabular}

FIGURE 5 The direct line of male ancestors of Henry Norman Bethune, extending back over II generations to the Bethunes/Beatons of Husabost in Skye. Dates in square brackets are dates obtained from legal documents indicating that the individual was alive at the time.

\section{THE EARLY HISTORY OF THE MACBETHS, BEATONS AND BETHUNES}

The MacBeths originally came from Ireland to Scotland.Their Gaelic name Macbethad or Macbheatha meaning 'son of life' is unusual in not being patronymic - most clan names honour a famous or eponymous ancestor. A name embodying 'life' is appropriate for a hereditary family of physicians, and the connection may not be coincidental.
The early genealogy is made more difficult to interpret by the use in some documents of the occupational name Leich or Leiche (in Gaelic lighiche or léigh), meaning doctor, as the only surname. A further difficulty is the wide variation in spelling of the Gaelic, Latin and English variants of the name which includes MacBeth and MacVay variants.

The first branch of the medical dynasty of MacBeth of which we are aware became established in Islay in the Parish of Kilchoman and spread from there initially to other Scottish islands. ${ }^{29}$ It is likely that they had learned their medicine in Ireland ${ }^{30}$ where there was a long established tradition of dynastic Celtic medicine. The family became physicians to the kings of Scots when in I 379 Robert II confirmed a grant of lands in Melness and Hope in Sutherland to an early MacBeth, Ferchard Leiche, who was styled 'medicus noster'. ${ }^{31}$ In 1386 the king made him a further grant of the islands of Jura (now Oldany), Calwa, Sanda and other smaller isles lying of the north and northwest coast of Scotland. ${ }^{32}$

The anglicisation, or more correctly, latinisation, of the name to Beaton by some members of the kindred began to be seen in documents in the early I5th century, initially in non-Gaelic contexts. The first Beaton recorded in Islay is Fergus Beaton who witnessed, signed with his own name and probably drew up a charter recording a grant of land from Donald, Lord of the Isles in 1408, ${ }^{33}$ indicating that the MacBeths/Beatons had become physicians to the Lords of the Isles by that date. The dynasty survived the demise of the Lords of the Isles in the late fifteenth century and were able to retain their status as royal physicians. A Gilchrist MacBeth, surgeon ('Gilchristus McVaig, Surrigus'), is listed as crown tenant in 1506, which in that context suggests a royal appointment. ${ }^{26,27,34,35}$ In 1609 a charter by James $\mathrm{VI}$ of Scotland describes Fergus MacBeth of Islay as physicianin-chief in the Isles. ${ }^{36}$

\section{BEATONS AND BETHUNES}

From the mid-17th century all but two of the 18 or so surviving medical families of the clan used the name Beaton in all English and Latin contexts. The exceptions were the Bethunes of Husabost in Skye, from whom Henry Norman Bethune was descended, and the Bethunes of Culnaskea in Ross-shire who both adopted the Bethune form of the name, believing that they were descended from the Bethunes of Balfour, in Fife, an opinion confirmed as a family belief by Whyte's account. It now seems more likely, as explained above, that they did not originate in Fife or France but were descended from the MacBeths, originally from Ireland who had changed their name to Beaton and subsequently to Bethune. ${ }^{12,25-27}$

The name Bethune derives ultimately from 'de Béthune' 
which originated in northern France, in the town and arrondissement of Bethune in the Pas-de-Calais area of Normandy. It is likely that the forebears of Robert de Bethune (died II48), Bishop of Hereford, came from France with the Norman conquest, ${ }^{32}$ and a sept of the family became established in the counties of Fife and Angus sometime in the 13th century. ${ }^{36,37}$ In the late 15th century a Robert de Bethune married into the Balfour family of that ilk, establishing the lineage of Bethunes of Balfour. In Scotland from the 15th century, some Bethune families began to anglicise the name to Beton or Beaton, although some, like the Balfour sept in Fife, continued to use the original Bethune spelling, but pronounced the name as 'Beaton'.

The many families of medical Beatons/Bethunes practising in Gaelic Scotland have been described in detail by Bannerman ${ }^{12}$ who identified 76 Beaton/Bethune physicians between 1300 and 1750 . It is likely that there were even more medical Beatons who used the generic occupational surname Leich or Leiche rather than their kindred surname.

The MacBeth/Beaton/Bethune medical kindred were much more than practitioners of folk medicine in the oral tradition. They had access to the corpus of European medical knowledge and used many of the great works of classical medicine, including those by Hippocrates, Galen, Avicenna, Averroes and Joannes de Vigo and de Gordon, many of which were translated into Gaelic and survive today in libraries around the world.$^{38}$ The large collection of Gaelic manuscripts in the National Library of Scotland, which contains many that were owned or written by the Beatons, has been described in detail by Comrie. ${ }^{39,40}$ By the start of the

\section{REFERENCES}

I Walt AJ.The world's best-known surgeon. Surgery 1983; 94:582-90

2 Stewart R, Stewart S. Phoenix: the life of Norman Bethune. Montreal, London: McGill-Queen's University Press; 2011.

3 Shenwen L. Henry Norman Bethune. In: Dictionary of Canadian Biography [online].Toronto: University of Toronto; 1990.

4 MacDougall H. Norman Bethune. In: Dictionary of Canadian Biography [online]. Toronto: University of Toronto; 1990.

5 Hudson's Bay Company Archives. Bethune, Angus (I783-1858) [Internet]. Winnipeg: HBCA; 1997 [cited 2013 June 12]. Available from: http://www.gov.mb.ca/chc/archives/hbca/biographical/b.html

6 Russell H. Angus Bethune. In: Dictionary of Canadian Biography [online]. Toronto: University of Toronto; 1985.

7 Newman PC. Caesars of the wilderness: the story of the Hudson's Bay Company. Toronto: Penguin Canada; 1988.

8 MacKenzie J. John Bethune (I75I-I8I5) (NLS 6.2592). Edinburgh: National Library of Scotland.

9 Sabine L. Biographical sketches of loyalists of the American Revolution, with an historical essay. Boston: Little, Brown and Company; 1864. p. 227.

10 McDougall EA. John Bethune. In: Dictionary of Canadian Biography [online]. Toronto: University of Toronto; 1983.

II Whyte T, Constable A, Jamieson J. An historical and genealogical account of the Bethunes of the Island of Sky. Edinburgh: Neill and Company; 1778. 18th century the Beaton/Bethune kindred were no longer dynastic physicians, as the increasingly anglicised clan chiefs turned to lowland doctors trained by formal apprenticeship or to graduates from the newly established university medical schools.

\section{CONCLUSION}

It has been possible to establish that Henry Norman Bethune is indeed descended from the famous Bethune/ Beaton medical kindred. His roots have been traced back to the Husabost component of the family, which is probably the best known branch of the kindred. His direct ancestors served as physicians to the MacLeods of Dunvegan, one of the largest and most powerful of the Scottish clans. Although his claim that he was descended from an unstable and wrongheaded race may have applied to some of his family, such as his grandfather and great-grandfather, many of his earlier ancestors were clearly men of vision and drive who were part of an extraordinary dynastic medical institution that lasted for 450 years and may well be unique in Western medicine.

\section{Acknowledgements}

The genealogical information about the Skye Bethunes was validated by Norma MacLeod of Skye Roots (www.skye-roots.co.uk), who also provided valuable genealogical advice. We are grateful to Roderick Stewart for helpful comments and suggestions about the Bethunes in Canada. The genealogy research was aided by a grant to one of the authors (AM) from the Douglas Guthrie Fund.

I2 Bannerman J. The Beatons a medical kindred in the classical Gaelic tradition. Edinburgh: John Donald; 1986.

13 The National Archives of Scotland (www.scottishdocuments.com). Synod of Glenelg. Minutes, 1750-1785 (CH2/568/2) [Internet]. Edinburgh:The National Archives of Scotland [cited 2013 June 13]. Available from: http://www.scottishdocuments.com/placePage. aspx?placeRef=|826 |

14 Scott H. Fasti Ecclesiae Scoticanae: the succession of Ministers in the Church of Scotland from the Reformation. Edinburgh: Oliver and Boyd; 1928.

15 The National Library of Scotland. Letter of Allan MacDonald, Kingsburg to John Mackenzie of Delvine, concerning emigration from Skye to North Carolina, and its consequences for the Island, 2 March 1773 (Delvine Papers, MS.I306, f.68) [Internet]. Edinburgh: NLS; 1773 [cited 2013 June 12]. Available from: http://digital.nls.uk/ emigration/preparing/macdonalds/letter-I773.html

16 The National Library of Scotland. Letters of Flora MacDonald, I 772 to John Mackenzie of Delvine, concerning the Macdonalds imminent emigration to America, 12 August 1772 (Delvine Papers, MS. I306, f.72) [Internet]. Edinburgh: NLS; 1772 [cited 2013 June 12]. Available from: http://digital.nls.uk/emigration/preparing/ macdonalds/letter-I772.html

17 Hunter J. A dance called America: the Scottish Highlands, the United States and Canada. Edinburgh: Mainstream; 1994. 
18 Hunter J. Scottish exodus: travels among a worldwide clan. Edinburgh: Mainstream; 2005.

19 Canniff W. History of the settlement of Upper Canada (Ontario): with special reference to the Bay Quinte. Toronto: Dudley \& Burns; 1869.

20 Dobson D. Directory of Scottish settlers in North America, 1625 1825. Baltimore: Genealogical Pub. Co.; 1984.

21 National Library of Scotland. Gaelic manuscript LX. (Adv. MS.72.2.10). Edinburgh: NLS.

22 Dunvegan papers. In: Bannerman J. The Beatons: a medical kindred in the classical Gaelic tradition. Edinburgh: John Donald; 1986.

23 Demaitre L. Theory and practice in medical education at the University of Montpellier in the thirteenth and fourteenth centuries. J Hist Med Allied Sci 1975; 30:103-23. http://dx.doi. org/I0.1093/jhmas/XXX.2.I03

24 Pearn J. Bernard de Gordon (f। | 270-1330): medieval physician and teacher. J Med Biog 2013; 21:8-1I. http://dx.doi.org/I0.1258/ imb.2011.011026

25 MacKinnon D. Gaelic medical MSS and their authors. Edinburgh Medical Journal 1894-95; 40:729-33.

26 Gillies HC. A Gaelic medical manuscript of 1563. Caledonian Medical Journal 1902;5:39-86.

27 Gillies HC. Regimen sanitatis, the rule of health: a Gaelic medical manuscript of the early sixteenth century or perhaps older from the Vade mecum of the famous Macbeaths, physicians to the Lords of the Isles and the Kings of Scotland for several centuries. Glasgow: R Maclehose \& Co., Ltd.; I9II.

28 MacKinnon D. A descriptive catalogue of Gaelic manuscripts in the Advocates' library, Edinburgh, and elsewhere in Scotland. Edinburgh:W Brown; 1912.
29 MacKinnon D. Genealogy of the MacBeths or Beatons of Islay and Mull. Caledonian Medical Journal 1902; 5:I4I-53.

30 Hamilton D. The healers: a history of medicine in Scotland. Edinburgh: Mercat Press; 2003.

3 I Boardman SI. The early Stewart kings: Robert II and Robert III, |37I-/ 406. East Linton:Tuckwell Press; 1996.

32 Barrow J. Béthune, Robert de (d. I I48). In: Goldman L, editor. Oxford Dictionary of National Biography. Oxford: OUP; 2012

33 Smith GG. The book of Islay. Documents illustrating the history of the island. Edinburgh: Privately printed; 1895.

34 Macphail JRN. Highland papers. Edinburgh: Scottish History Society; $19 \mid 4$

35 Thomson DS. Gaelic learned orders and literati in mediaeval Scotland. Scottish Studies 1968; 12:60-5.

36 Thomson JM (ed). The register of the Great Seal of Scotland (vol. 7), AD. I609-1620. Edinburgh: HM General Register House; 1892.

37 Watson WJ. Rosg Gaidhlig. Specimens of Gaelic prose. 2nd ed. Glasgow: An Comunn Gaidhealach, printed by Alex MacLaren; 1929. Gaelic.

38 Mackechnie J. Catalogue of Gaelic manuscripts in selected libraries in Great Britain and Ireland. Boston: GK Hall; 1973.

39 The National Library of Scotland. Gaelic manuscripts in the National Library of Scotland: old and new reference numbers [Internet]. Edinburgh: NLS [cited 2013 June 13]. Available from: http://www. nls.uk/media/22586/gaelic-reference-number-concordance.pdf

40 Comrie JD, Wellcome Historical Medical Museum. History of Scottish medicine. 2nd ed. London: Bailliere, Tindall \& Cox; 1932.

4I Campbell R. A history of the Scotch Presbyterian Church, St Gabriel St, Montreal. Montreal:W Drysdale \& Co; 1887. 